\title{
Wage Arrears, Poverty, and Family Survival Strategies in Russia
}

by

Padma Desai, Columbia University Todd Idson, Columbia University

October 1998

Discussion Paper Series No. 9899-05 


\title{
Wage Arrears, Poverty, and Family Survival Strategies in Russia
}

\author{
Padma Desai \\ Columbia University \\ and \\ Todd Idson \\ Columbia University
}

October 1998

We thank Richard Ericson, Vladimir Gimpelson, Anatoly Kandell, Laura Kline, Vladimir Mikhalev, Richard Nelson, Joan Nelson, Vladimir Popov, David Woodruft and workshop participants at Columbia University, the City University of New York Graduate Center, the London School of Economics, Yale University, and the University of Kentucky, for helpful comments. We are responsible for the errors that remain. 


\begin{abstract}
In this paper we use a longitudinal survey of Russian households for analyzing the impact of wage arrears on the incidence of poverty among families and their survival strategies. The failure of enterprises and government to fully pay workers in a timely fashion is shown to be associated with a higher incidence of poverty; a similar effect is found for pensioners experiencing pension arrears. As a result of pay delays, we find that individuals and families were more likely to take second jobs, increase home production for own-consumption and sale, reduce their rate of saving, sell family assets, and receive transfers of goods and money from relatives (which, in turn, reduce the effect of wage nonpayment on poverty). Wage nonpayment also contributed to a rise in barter between workers and firms, although the monetary value of these goods and services did little to arrest the upward trend in outstanding net debt to workers.
\end{abstract}




\section{Introduction}

Throughout the course of the transition, Russian enterprises and federal as well as regional governments have repeatedly failed to fully pay large segments of their employees. ${ }^{1}$ The wage nonpayment problem worsened over time, by 1996 leading to a sustained public outcry and increased union militancy. ${ }^{2}$ The upward trend in arrears is seen in the table below which focuses on the three sectors of the economy for which Goskomstat has published information on wage arrears

Trends in Sectoral Wages Arrears

\begin{tabular}{|c|c|c|c|}
\hline \multicolumn{4}{|c|}{ Trends in Sectoral Wages Arrears } \\
\hline \multicolumn{4}{|c|}{ (1) Outstanding wage arrears (billions of December 1995 rubles) } \\
\hline & Industry & Construction & Agriculture \\
\hline 1992 & 1,034 & 541 & 397 \\
\hline 1993 & 2,653 & 840 & 2,092 \\
\hline 1994 & 5,019 & 1,686 & 3,009 \\
\hline 1995 & 7,734 & 1,941 & 2,571 \\
\hline 1996 & 18,185 & 5,310 & 4,855 \\
\hline \multicolumn{4}{|c|}{ (2) Ratio of outstanding wage arrears to the monthly wage bill (percent) } \\
\hline 1992 & 5 & 6 & 6 \\
\hline 1993 & 13 & 10 & 36 \\
\hline 1994 & 31 & 23 & 68 \\
\hline 1995 & 61 & 40 & 102 \\
\hline 1996 & 111 & 74 & 158 \\
\hline
\end{tabular}

SOURCE: Russian Economic Trends, 1997.1

'While public perception has focused on government wage nonpayment, only about 20 percent of outstanding arrears are owed to government employees, the remaining wage debt being owed to workers in privatized enterprises.

${ }^{2}$ Strikes by hard hit groups, among them coal miners, teachers, and nuclear power workers increased substantially by 1996 . Union militancy on this issue has attempted to bring the plight of Russian workers to the attention of the international community through the establishment of a cybercampaign focused on the nonpayments crisis (this site may be reached at www.icem.org/campaigns/no_pay_cc/index.html). 
since the beginning of the transition. ${ }^{3}$ The constant dollar value of outstanding wage arrears consistently increased between 1992 and 1996; by approximately 17-fold in industry, 10-fold in construction, and 12-fold in agriculture. As a percentage of the sector's monthly wage bill, the increase was approximately 22-fold in industry, 12-fold in construction, and 26-fold in agriculture.

Although the wage arrears crisis has received much public attention, there is a paucity of research addressing the impact of wage nonpayment on Russian workers and the ways in which individuals and families have responded to pay delays. In this paper, we employ longitudinal data relating to Russian households for analyzing these questions. Specifically, we look at the effect of arrears on the incidence of family poverty ${ }^{4}$; supplemental economic activity such as multiple job holding and less formal, paid economic activity; home production for consumption and sale; various forms of dissavings such as taking out loans, withdrawing savings, and selling family assets; and increased intra-family transfers from relatives to people experiencing nonpayment. We also consider the role of home production and income transfers from relatives in mitigating the impact of wage arrears on poverty; and barter arrangements between enterprises and workers.

\section{Wage Arrears, Pension Arrears, and Poverty}

Our assessment of the impact of wage arrears on the Russian people utilizes the Russian Longitudinal Monitoring Survey, a longitudinal data set of Russian households and individuals. ${ }^{5}$ We focus on the years 1994-96 for which data on wage arrears are available. These questions were asked of all respondents who indicated that they were either at work or on unpaid or paid leave. Our analysis focuses on the subset of people aged 17-64 who were receiving positive wages from their

${ }^{3}$ Comparison of total wage arrears in 1996 to earlier years is problematic because sectors for which wage arrears are reported are not comparable: only medium and large-sized enterprises in industry, construction, and agriculture reported data on wage arrears from 1992-94; the transportation sector was added in 1995; in 1996, four noncommercial sectors were added -- health care, education, culture, and science.

${ }^{4}$ Wage nonpayment not only reduces family disposable income directly but also cuts into family wealth because wage arrears are not indexed. This means that even if Russian workers were to be eventually repaid, they would have suffered a significant loss given the high monthly inflation rates that persisted through 1995 (and, while having fallen in 1996, were still as high as 20 percent at the end of the year).

${ }^{5}$ Information on the structure of the survey, the questionnaires, and data sources may be obtained over the internet at http://www.cpc.unc.edu/rlms. 
primary jobs at the time of the interviews.

Table 1 investigates the relationship between wage arrears and the incidence of poverty. ${ }^{6}$ Three conclusions follow from the analysis. Poverty, measured in terms of the percentage of people who were in families with incomes below regional poverty thresholds, had increased in Russia during the transition irrespective of whether people were owed wages.' When we compare the two rows in panel (A), we see that (i) the percentage in poverty was higher in all years for people who were owed wages and (ii) the incidence of poverty had increased more rapidly between 1994 and 1996 for people who were owed wages.

The multivariate analysis reported in panel (B) shows that this impact of wage arrears on poverty, captured by the indicator variable $P$ jowed ${ }^{8}$ remains highly significant even after we control for demographic and job market attributes of the respondents. Again, the effect of wage arrears on the likelihood of a family being in poverty increased between 1994 and 1996 as reflected by the significant and positive interaction effects; wage nonpayment increased the likelihood of a respondent being in poverty by 8.9 percent in 1994 (once again, relative to people who did not have some portion of their wages withheld), by 12.3 percent in 1995 , and by 13.6 percent in $1996 .{ }^{9}$

We extend our analysis of the impact of payment arrears on poverty by investigating the impact of pension arrears in Table 2. Nonpayment of pensions, or pension arrears, has progressed

${ }^{6}$ Our indicator variable which defines the regional poverty thresholds is $P o v$ index, a dummy $=1$ if family income (adjusted for the structure of the family, i.e. number and age of children, number and gender of adults, number of elderly) falls below the poverty threshold, and 0 if family income does not fall below the poverty threshold. The threshold is calculated on the basis of a subsistence minimum consumption bundle, using subsistence food amounts for approximately 55 food items for five demographic groups (young children, older children, adult males, adult females and the elderly), and regional average prices for each item (that are calculated for ten regions).

${ }^{7}$ See Popkin and Mroz (1995), Mikhalev (1996), Milanovic (1996), Gregory (1997) and Klugman (1997) for discussions of trends in Russian poverty and issues relating to its measurement.

${ }^{8}$ The variable Pjowed is based on the survey question, "At the present time, does your place of work owe you any money, which for various reasons was not paid on time?" The response is coded as 1 if the respondent said "yes" and as 0 if the respondent said "no". The value of this variable increased from approximately 26 percent in 1994 to approximately 40 percent in 1996.

${ }^{9}$ These values are based on transformations of the reported coefficients of the interaction terms in specification (2) into slopes evaluated at the means of the explanatory variables. 
during the transition hand-in-hand with wage arrears. ${ }^{10}$ Respondents were first asked if they currently received a pension, and, if they responded affirmatively, they were next asked if they "receive(d) a pension in the last 30 days". We use this latter question to quantify the incidence of pension arrears. Although pensions were occasionally received by people who were still working, we focus our analysis on pension recipients who indicated that they had retired. ${ }^{11}$

Considering first the incidence of pension arrears, we see in column (1) in panel (B) that pension arrears, net of the effects of the control variables, increased significantly over the period: the estimated year effects rise from 0.566 in 1995 to 1.585 in 1996 in a regression with a dummy dependent variable (Pens30) that equals one if the respondents failed to receive their pensions in the past 30 days. ${ }^{12}$ We next assess the impact of pension arrears on pushing people into poverty. In panel (A) we report simple mean comparisons of poverty incidence in terms of whether or not people were experiencing pension arrears. We notice that the poverty rates were significantly higher for people facing pension arrears in all years: in 1996,69.5 percent of the people in our sample who were experiencing pension arrears were poor, while only 10.5 percent of the sample who were not experiencing pension arrears were poor. The last two columns of Panel (B) extend this inquiry by investigating the net effect of pension arrears on the likelihood that a person will experience poverty. The significantly positive coefficient of our indicator variable for the presence of pension nonpayment in column (2), 1.639, indicates that pension arrears per se increased the likelihood of poverty. Furthermore, we see from the increasingly positive coefficients of the interaction terms in column 3 that incurring pension arrears had a stronger (positive) effect on the likelihood of pensioners falling into poverty over the 1994-96 period, i.e. the estimated effect rises from 1.332 in 1994 to 1.459 in

${ }^{10}$ On July 1,1997 , as promised, the Yeltsin government repaid all outstanding pension debts. Although this element of the nonpayment crisis was temporarily resolved, the lack of structural reforms and improvement in tax collection for the Pension Fund has caused renewed accumulation of pension arrears.

"Data from the RLMS indicate that 12.1 percent of respondents who indicated that they were employed at the time of the survey, also received a pension; similarly, 10.2 percent of the people who indicated that they were not retired responded that they were receiving a pension. These results are averaged over the 1994-96 period.

${ }^{12}$ The coefficients of the control variables (not presented in the Table) reveal that (i) there was no difference in arrears incidence for women, (ii) arrears decreased with age, (iii) arrears were lower for the most educated, and (iv) all regions had lower pension arrears than in Moscow and St. Petersburg, with substantial variation in arrears across regions as evidenced by the large variation in the regional coefficients. (The full results are available on request.) 
1995 and again to 1.756 in 1996 . Although we do not have evidence on the magnitude of pension arrears, this effect implies that the ruble value of outstanding pension arrears increased over time.

\section{Family and Individual Responses to Wage Arrears}

How do families get by when they are not paid? Presenting below a number of survival mechanisms at play in Russia in response to wage arrears, we examine their impact in moderating the incidence of poverty among households.

\section{Secondary Job Holding and Informal Paid Work}

People tended to respond to wage nonpayment by taking secondary jobs and engaging in informal, supplemental work for pay. ${ }^{13}$ Traditional models of moonlighting behavior argue that workers take second jobs when they are underemployed on their main job, which is defined as workers desiring more work hours than their main employer makes available to them, i.e. the wage rate on their main job is greater than their marginal rate of substitution between earnings (consumption) and leisure at current hours of work (see Shisko and Rostker, 1976). This framework assumes that workers are paid for hours of work, i.e. they are underemployed if they want to earn more income by working more (paid) hours. Nonpayment of wages may be seen in a similar light: workers, unable to generate their desired income on their primary jobs, ${ }^{14}$ engage in supplemental employment in order to meet their income goals. From that perspective, the wage arrears crisis can have real effects on the economy, in addition to those generated by changes in expenditure due to changes in disposable income, by inducing labor supply responses in the form of supplemental economic activity. ${ }^{15}$

We consider two forms of secondary economic activity. The variable $A d p d j b$ is a dummy that

${ }^{13}$ See Foley (1997) for a study of patterns in multiple job holding in Russia during the transition.

${ }^{14}$ Depending on management behavior, it might be more accurate to model the labor supply effects of wage arrears as a cut in wage rates (in the case where management tends to withhold pay based on a percentage of earnings) or a limitation on available paid hours (in the case where management tends to cease payments after a certain threshold level of earnings is reached).

${ }^{15}$ Wage arrears may also produce labor supply effects in primary employment, i.e. increase quits from enterprises and sectors that fail to fully pay their wage obligations. The Soviet-era linkage of social services and housing to the employing enterprise limits these mobility responses. 
indicates whether or not a person holds a second job for pay in formal secondary employment. ${ }^{16}$ By contrast, the variable Engiea is a dummy that indicates whether or not the respondent does additional work for pay although the actual survey question clearly addresses less formal types of work, largely self-employment activities. ${ }^{17}$ In the RLMS sampling procedure, the former question was only asked of people who reported that they currently held a job whereas the latter was asked of all respondents. However, our sample restrictions ensure that in both cases we are considering the same group of people. ${ }^{18}$ As noted above, we have restricted our sample to people who indicated that they held a job (the wage arrears questions were only asked of these people), and we further impose the sample restriction of positive wage payments thereby deleting from the sample people who held jobs but were currently on voluntary or involuntary leave.

The simple univariate patterns in panels (A) and (B) of Table 3 suggest that people who were owed wages were more likely to hold second jobs (Adpdjb) in 1995 and 1996, and were more likely to engage in supplemental individual economic activity (Engiea) in all years. For example, in 1996 5.9 percent of the people who were owed wages held second jobs, while only 4.1 percent of our sample who were not owed wages held second jobs; similarly, 7.9 percent of respondents who were owed wages engaged in informal work for pay, while 4.8 percent of those not owed wages did so. In panel (C), the significantly positive coefficients of Pjowed ( 0.147 for the Adpdjb regression and 0.232 for the Engiea regression) indicate that this relationship remains robust when we include other covariates, providing compelling evidence that wage nonpayment had distinct labor supply effects with respect to multiple job holding and less formal supplemental work. While wage arrears allowed enterprise managers to retain redundant workers by providing downward wage flexibility (see Desai

\footnotetext{
${ }^{16}$ The variable $A d p d j b$ is based on the survey question, "Tell me, please, do you have some other kind of work?" The response is coded as 1 if the answer is "yes" and as 0 if the answer is "no."

${ }^{17}$ The variable Engiea is based on the survey question, "Tell me, please, in the last 30 days did you engage in some additional kind of work for which you got paid? Maybe you sewed someone a dress, gave someone a ride in a car, assisted someone with apartment or car repairs, purchased and delivered food, looked after a sick person, or did something else that you were paid for?" The response is coded as 1 if the answer is "yes" and as 0 if the answer is "no".

${ }^{18}$ These sample restrictions may bias our estimates of supplemental work activity and the effects of arrears on supplemental labor supply decisions because people on leave will tend to have different incentives for engaging in supplemental work from those currently receiving wages. The direction of the bias is also not obvious because those on voluntary leave, including maternity leave, might have relatively high reservation wages during their leave and might be less likely to find alternative work while those on involuntary leave might be in greater need of supplemental income.
} 
and Idson, 1998), they also acted to stimulate employment (measured by total hours worked) and output through these induced labor supply effects. ${ }^{19}$

\section{Intra-Family Transfers}

Do people who suffer from wage nonpayment receive help from relatives? ${ }^{20}$ The following excerpt from an ICFTU (International Conference of Free Trade Unions) newsletter on the wage arrears crisis illustrates the situation:
"How do people manage to survive for months without receiving any wages?, is the question regularly asked by visitors from the West. So we asked Larisa Seliverstova, the chairperson of the trade union committee of school number 10 in Prokop'evsk, Kemerovo oblast, about the budget of her own family. 'How do you survive? Does someone help you?' 'Our parents help: my husband has two and I have one. My father gives us all of his pension - he is still working. My husband's mother helps us with food. Grandpa and grandma completely support our child. They live in a private house which has a garden, and they also have an allotment."' (ICFTU Campaign on the Non-payment of Wages in Russia, Newsletter No. 2, September 1997).

In this section we analyze the income supplements received by workers with wage arrears from family members, i.e. from parents giving money to working (adult) children, adults giving money to working parents, and relatives, among them aunts, uncles and grandparents providing support to cash-strapped relatives. ${ }^{21}$ We also analyze if wage nonpayment results in people giving less material help to family members. ${ }^{22}$

${ }^{19} \mathrm{We}$ also find, in results not reported here, that women were less likely than men to engage in supplemental work activities perhaps due to family obligations. When we split the sample by gender, we again find that wage arrears had a significant and positive effect on supplemental labor supply for men, but an insignificant (though positive) effect for women possibly reflecting family constraints and/or gender differences in secondary job market opportunities. (These results are available on request.)

${ }^{20} \mathrm{Cox}$, et al. (1997) found that intra-family transfers were pervasive in Russia during the years 1992 and 1993 and served to reduce poverty.

${ }^{21}$ The survey question is: "Has your family received money, food, clothes, or other goods in the last 30 days and, if so, how would you assess this aid in rubles?" Sources of aid from either spouse's parents, children, grandparents, grandchildren, and/or other relatives are counted as intra-family transfers.

${ }^{22}$ Our measure is based on the survey question: "Has your family or one of its members given or sent money or goods - food, clothes, other items - without obligation to people who are not members of your household - children, parents, other relatives, friends, or simply strangers - in the last 30 days?" Transfers to either spouse's parents, children, grandparents, or grandchildren are included in the measure. 
The simple averages listed in panel (A) of Table 4 indicate that in all three years from 1994 to 1996, the likelihood of receiving a transfer (rows 3) was higher for people who faced arrears, although, conditional on receipt of a transfer, the amount received (rows 4) was no higher for those facing arrears than for those not facing arrears. Respondents who were experiencing wage nonpayment were less likely to give money (and/or goods) to relatives in 1995, although in 1994 and 1996 wage arrears did not seem to influence transfers to relatives (rows 1). Among people who did give money (and/or goods) to relatives, the amount given (rows 2) was lower in 1995 and 1996 when the donor was suffering from arrears. In Panel (B) we see from the estimated coefficients of Pjowed that these patterns persist even after we control for demographic attributes and other variables. The negative coefficients of Pjowed in the first and second regressions, -0.067 and -97870.98 respectively, suggest that wage nonpayment was associated with a decrease in the material help given to relatives. The positive coefficient of Pjowed in the third regression (0.143) suggests that people who were not receiving their full pay were more likely to receive material help from relative, although the insignificant coefficient of Pjowed in the third regression (-9243.58) indicates that the amounts given were not related to the presence of wage debt. ${ }^{23}$

\section{Home Production for Consumption andior Sale}

Families may also engage in own-production of goods for consumption and/or for sale in order to maintain their standard of living. Simple averages of home produced food ${ }^{24}$, reported in Panel (A) of Table 5a, reveal that home production of harvested food for self consumption was greater among people who were owed wages (rows 1 ). We also notice (rows 2 ) that people who were owed wages were more likely to produce agricultural products for sale, ${ }^{25}$ and the average value of these goods, conditional on any production being undertaken (rows 3 ), was higher for individuals who were owed wages. It is possible, though, that these univariate patterns might simply reflect

\footnotetext{
${ }^{23} \mathrm{We}$ also found that these relationships between arrears and transfers were constant during 1994-96, with the exception that in 1996 the ruble value of transfers to family members, conditional on a transfer taking place, was significantly lower among donors who suffered from wage arrears than was the case in 1994 (the results are available on request).

${ }^{24}$ These goods include any of 25 different foods that may have been grown/harvested on land that the family either owns or leases (a detailed list of food items is available on request).

${ }^{25}$ These goods include items referred to in footnote 23, plus sales of livestock, poultry, bees/honey, wool/down, milk, eggs, hides, mushrooms, nuts, berries and fish.
} 
higher levels of wage arrears in regions where the use of private plots of land for agricultural purposes was more widespread. However, when we introduce control variables into the analysis, in Panel (B), the relationship between arrears and own-production persist, suggesting that the impact of wage arrears on home production documented in Panel (A) is not simply reflecting the influence of secondary relationships such as the location of the household that are associated with the incidence of wage arrears.

\section{Household Savings and Dissavings}

Families may also maintain consumption patterns by varying their rate of savings and by engaging in various forms of dissaving including borrowing (loans), selling family consumer durables and other assets, and drawing down accumulated savings. We analyze family dissaving in Table $5 \mathrm{~b}$ followed by changes in savings rates in Table $5 \mathrm{c}$. Table $5 \mathrm{~b}$ reports evidence that people who were owed wages were more likely (than people who had been fully paid) to sell some of their family assets (rows 1$)^{26}$ and to take out loans (rows 2), although conditional on taking out a loan, people facing wage delays tended to borrow smaller amounts (rows 3 ), a result most likely due simply to difficulties in qualifying for larger loans. Panel (B) reveals that these wage arrears effects persist when control variables are introduced: the positive estimated effects of Pjowed on the tendency of respondents to sell family assets (0.206) and to take out loans (0.338) suggest these survival mechanisms are a genuine response to the arrears crisis, rather than reflecting the association of the incidence of nonpayment with regions or industries (for example) where the tradition or opportunity for home-production is most pronounced.

Do people tend to save less and in smaller amounts, and to withdraw money from their savings when faced with wage nonpayment? The simple mean comparisons in Panel (A) of Table $5 \mathrm{c}$ indicate that people facing wage nonpayment were less likely to save money, e.g. in 1996 only 6.5 percent of the respondents who experienced wage arrears saved any money, while 9.6 percent of those people not experiencing wage arrears had positive savings rates. In Panel (B) the significantly negative estimated effect of Pjowed (-0.137) indicates that this result persist even when controls for

\footnotetext{
${ }^{26}$ Respondents were asked if they owned any of the items in a list of seven different consumer durables, plus cars, boats, apartments and houses, and then asked, "In the last 3 months has your family sold any of their things in order to get enough money for food and clothing?"
} 
respondent attributes and family location are taken into account. However, the insignificant mean comparisons in last three rows of Panel (A), in addition to the insignificant effect of Pjowed in the last three regressions in Panel (B), suggest that the other potential survival mechanisms were not important in Russia during the 1994-96 period: i.e., although people experiencing wage arrears were less likely to save (conditional on positive savings), people who were owed wages had average savings levels similar to those for people who were fully paid, and people did not seem to compensate for wage arrears by living off their savings. It may well be that savings were generally so low that few people could meaningfully make use of this last adjustment mechanism.

\section{Wage Arrears and Poverty: The Effect of Intra-Family Transfers and Home-Production}

We have seen above that wage arrears were positively associated with the incidence of poverty, that they increased transfers from relatives, and raised home production. Do these higher levels of intra-family transfers and home-production mitigate the effect of wage arrears on the incidence of family poverty? For addressing this question, we create three poverty indicators, each defining poverty status by the usual condition of incomes falling below specified (regional) income thresholds, or poverty lines. The first uses actual family income ${ }^{27}(P o v l)$; the second supplements this income measure by the monetary value of intra-family transfers (Pov2); the third supplements actual family income by the monetary value of home production (Pov3). Next we define two variables, Compl is a dummy equal to 1 when a person is classified as poor based on index Povl but is not classified as poor using index Pov2, and equal to zero when Pov1 and Pov2 yield the same poverty classification. The variable Compl thus signals if the monetary value of intra-family transfers raised total family income (including transfers) above the regional poverty threshold, that is, if the value of intra-family transfers were insufficient to move the individual out of poverty. The variable Comp2 is similarly a dummy, equal to 1 if a person is classified as poor using index Povl but is not classified as poor using index Pov3, i.e. it indicates if the monetary value of home production raises total family income (including home production) above the regional poverty threshold. Given our earlier finding that people who experienced wage arrears were more likely to

${ }^{27}$ We use the responses to the survey question, "How much did your family receive (from a primary or additional place of work) after taxes and other deductions in the last 30 days? If you were paid in the form of goods or services, what was the approximate value in rubles?" 
receive transfers from relatives and engage in home production, we expect that the inclusion of the value of these supplemental forms of income will more likely move people out of poverty when they are experiencing wage arrears than when they are being fully paid. ${ }^{28}$

The results from this analysis are reported in Table 6. Panel (A) provides simple comparisons of mean values for the variables Comp1 and Comp2. In 1994 and 1996, the values of Comp 1 are smaller in row 1 than in row 2 suggesting that intra-family transfers had a greater effect on moving people out of poverty for people experiencing wage arrears than for people who were fully paid. In 1996, for example, 5.19 percent of the people in our sample who were experiencing pay delays are classified as poor based on the poverty index that uses family income (Povl), but are not classified as poor if intra-family transfers are included in family income (Pov2): in other words, intrafamily transfers move 5.19 percent of the poor who suffer wage arrears out of poverty. By contrast, among people not experiencing pay delays, intra-family transfers move only 3.85 percent out of poverty. We observe similar patterns for home production, i.e. the inclusion of home production acts to move a higher percentage of people out of poverty when they experienced wage arrears ( 3.15 percent in 1996) than when they were fully paid (1.31 percent in 1996). ${ }^{29}$ The last two columns in Panel (B) provide the multivariate counterpart to the results in panel (A). The positive coefficients of Pjowed indicate that both intra-family transfers and home production are more likely to alleviate poverty for people experiencing wage arrears than for those who are fully paid.

As a complement to the above test, we also estimate the effect of wage nonpayment on the likelihood of poverty for each of our three poverty indicators, shown in the first three columns of Panel (B). Our expectation is that Pjowed will be a weaker (positive) predictor of poverty incidence when intra-family transfers (Pov2), or home production (Pov3), are included than when they are not taken into account (Pov1). Comparing the coefficients of Pjowed in the first column in panel (B)

${ }^{28}$ Given that wage arrears increase the likelihood of poverty, transfers might reduce the likelihood of wage arrears sufferers falling below poverty thresholds, while at the same time insufficient to move them above the given thresholds. An investigation of the effects of arrears per se, and of the alleviating effects of intra-family transfers, on the position of people in the income distribution of those in poverty remains for future work.

${ }^{29}$ We should emphasize that our results in Tables $4,5 \mathrm{a}, 5 \mathrm{~b}$, and $5 \mathrm{c}$ document a positive relationship between arrears and both intra-family transfers and home production, while the patterns reported in Table 6 show that these family responses to wage arrears significantly influenced the likelihood of their experiencing poverty. 
with those in the second and third columns, we find that wage arrears had a weaker effect on the likelihood of families being in poverty when intra-family transfers (column 2), or home production (column 3), are included as part of family income.

\section{Wage Arrears and Barter}

Along with escalating wage arrears, barter arrangements between enterprises and their employees, and among enterprises as payments for their output, increased between 1994 and 1996 (see Yakovlev, 1998; Aukutsionek, 1998)..$^{30}$ Countless examples of barter arrangements as alternatives to monetary payments have been noted in the press. To quote from an article from the BBC Online Network (August 24, 1998): "One factory in the City of Perm regularly pays its workforce in bicycles - which they then have to try and sell on the streets in direct competition with their employers." A more extreme occurrence was reported in the Chicago Tribune (October 12, 1997): "Russian seamstresses owed two years of back wages refused to accept coffins as barter payments, asking for grocery carts instead, the ITAR-Tass news agency reported. The workers at the Voskhod clothing plant in Yaya, about 1,900 miles east of Moscow, would use the carts -- worth about $\$ 21$ each -- to transport vegetables from their land plots. 'They are refusing to take the coffins in advance, explaining that they want to live and not to die,' the news agency said." Forms of near money that provide liquidity, facilitate transactions and contribute to price flexibility have also appeared (see Woodruff, 1996). Liquidity constraints have evidently contributed to wage arrears and barter of goods for labor services in Russia, in addition to the continually present incentives of lower tax liabilities associated with barter rather than monetary transactions. ${ }^{31}$

Wage nonpayment is clearly associated with enterprises providing partial payment to workers in the form of goods. We see in panel (A) of Table 7 that, among workers who were owed wages, 13

${ }^{30}$ The shortage of cash to pay wages is exacerbated by enterprise attempts to reduce the amount of cash flowing into company accounts as a way of avoiding cash tax payments. A large percentage of tax liabilities are instead paid through tax writeoffs accomplished with barter transactions between enterprises and the government. The extensive incentives for nonmonetary exchange in Russia has led to what some writers have called a demonetization of the Russian Economy (see Hendley, et al., 1998).

${ }^{31}$ Pendergast and Stole (1996) provide arguments for barter within organizations that are not based on liquidity constraints per se. Among these are the ability of enterprises to reduce excess inventories creating negotiations between enterprises and workers for mutually beneficial barter arrangements (see Roha and Schulhof, 1996) and use of goods as a source of price flexibility (see Stigler, 1969). 
percent received a portion of their compensation in the form of goods (Goodsp) 32 in 1994, the fraction dropping to 9 percent in 1995 and rising to 15 percent in 1996. Since these percentages are calculated from the base of people who were owed wages, which rose from 26 percent in 1994 to 40 percent in 1996, the growth in the prevalence of barter arrangements between 1994 and 1996 was greater than the 11 percent increase suggested by the comparison in Panel (A) between 13 percent in 1994 and 15 percent in 1996. Adjusting these latter estimates by wage arrears incidence, we notice that the percentage of our sample that received barter payments rose from 3 percent $(.2608 \times .1325)$ in 1994 to 6 percent $(.4042 \times .1468)$ in 1996 , resulting in a 71 percent increase in the incidence of barter payments compared to the 11 percent increase noted above. However, increased prevalence of barter (row 1) is not associated with higher barter payments (Goodsv, in row 2) ${ }^{33}$, so that barter payments would do little to counteract an upward trend in the value outstanding debt to workers (Amtowed).$^{34}$ These general patterns are seen in panel (B) to persist when we analyze them in a multivariate context: the negative coefficients of the 1995 year dummy (dum1995) indicate that the decline between 1994 and 1995 in the probability of occurrence ( -0.131 and -0.240 in regressions (1) and (2) respectively), and in the value of barter ( -0.351 in regression (3)) were significant, but the changes between 1994 and 1996 were not significant (as seen from the insignificant coefficients for the 1996 year dummy, dum1996).

While trends in barter between 1994 and 1996 are relevant for our analysis, our central focus is to check if barter transactions responded to the presence of wage arrears. As seen in Panel (B), regression (1), the positive coefficient of Pjowed ( 0.587 ) indicates that the likelihood of receiving

${ }^{32}$ The variable Goodsp is based on the survey question, "Have you received in the last 30 days at this enterprise in lieu of payment for your labor something from its production or from the production of another enterprise?" The response is coded as 1 if the respondent said "yes" and as 0 if the respondent said "no".

${ }^{33}$ The variable Goodsv is based on the survey question, "Estimate, please, how much the product you received cost in rubles, regardless of what you did with it?" Respondents skipped this question if they answered that they did not receive goods in lieu of wages (i.e. Goodsp=0).

${ }^{34}$ The variable Amtowed is based on the survey question, "How much money in all have they not paid you?" Respondents skipped this question if they answered that their employer did not owe them wages (i.e., Pjowed $=0$ ). This variable (significantly) increased from approximately 770,000 rubles in 1994 to approximately $1,081,000$ rubles in 1996 (both in December 1995 rubles). The value of outstanding wage debt net of the value of goods received in lieu of wages (Amtowed-Goodsv), increased from 741,738 in 1994 to $1,055,165$ in 1996 , indicating that barter payments to workers had only a small mitigating effect on the growth in outstanding debt to workers. 
barter was greater for respondents who were owed wages. ${ }^{35}$ Again, in specification (2), the significantly positive coefficient ( 0.189$)$ of $\ln ($ Amtowed) indicates that, among individuals who were owed wages, the likelihood of receiving goods increased with the ruble value of outstanding arrears. ${ }^{36}$ In regression (3), the significantly positive coefficient $(0.201)$ of $\ln ($ Amtowed) indicates that the value of the goods received, conditional on receipt of goods, also increased with the ruble value of outstanding arrears. ${ }^{37}$ These results provide evidence that barter transactions arose partly in response to wage arrears. We also see from the coefficient of 0.201 that a 10 percent increase in the value of outstanding wage debt was associated, on average, with only a 2 percent increase in the value of payment in the form of goods. Therefore, while barter payments may have the potential to mitigate the hardships to which employees were subjected by wage nonpayment, the magnitude and prevalence of payment in goods and services in lieu of wages to the sampled Russian households had only a small mitigating effect on the adverse impact of wage arrears.

\section{Conclusions}

Enterprise-based wage arrears, approximately 80 percent of the total, present a formidable problem defying an early resolution. In the short-run, a significant portion of government arrears could be cleared via settlement of tax arrears by large natural monopolies such as Gazprom, revenues from successive rounds of sale of government stocks in privatized companies and credits from international agencies. An effective solution to the problem in the budget sector requires a reform of the tax code, improved tax collection procedures, adoption of a realistic federal budget, and strict supervision of the disbursement of funds allocated to local governments. As for the privatized

\footnotetext{
${ }^{35}$ Evaluated at the means of the regressors, the probit estimate suggests that the likelihood of receiving barter payments was approximately 7.4 percent greater for respondents who faced wage nonpayment.

${ }^{36}$ In regression (2), we restrict the analysis to respondents who were currently owed wages. Therefore, the estimate of the variable $\ln$ (Amtowed) reflects the effect of the change in the value of outstanding debt to a worker per se rather than a combination of this effect and the likelihood of having his wage withheld, i.e. of observing a positive value for the variable Amtowed.

${ }^{37}$ If enterprise managers undertake barter transactions for enforcing wage flexibility in the presence of downwardly rigid nominal wages, then barter may decline if market forces result in lower wages. Markets require incentives for efficient functioning but traditions, administrative rules and political considerations generally work against wage flexibility. In that case, barter practices may increase. If firms resort to barter in response to liquidity constraints, then the prevalence and magnitude of barter may increase unless the macroeconomic environment improves and the nonpayments crisis is resolved.
} 
enterprises, wage nonpayment would decline in the long run if enterprise restructuring aimed at releasing excess labor moved forward, and bankruptcy laws leading to closure of unviable enterprises were to be enforced. ${ }^{38}$ Short of such decisive measures, wage and pension nonpayment are likely to persist, imposing widespread costs on the Russian population.

Our analysis based on an empirical investigation of household and individual data from 1994 to 1996 provides five main findings concerning the impact of wage and pension arrears on Russian workers and the survival mechanism that they devised for containing the adverse effects of being denied wages.. First, the prevalence of both wage and pension arrears rose over the period, intensifying the incidence of poverty among workers and pensioners. Second, wage arrears produced labor supply effects in that workers denied wages took second jobs and engaged in informal paid activities. Third, workers experiencing wage arrears were more likely to receive transfers of money and goods from relatives, and were less likely to give money (and goods) to their relatives. Furthermore, the response of intra-family transfers to wage arrears reduced the positive impact of wage nonpayment on the likelihood that a family would fall into poverty. Fourth, wage arrears were positively associated with home production of food items, acted to reduce savings rates, and caused families to sell their assets and to take out loans. As is the case with intra-family transfers, the sale of family assets in response to wage nonpayment acted to partially mitigate the positive effect of wage arrears on the incidence of poverty. Finally, while workers denied wages were more likely to be paid in barter, the magnitude of barter payments had only a small mitigating effect on the upward trend in wage arrears.

${ }^{38}$ In September 1998, Russia's new Prime Minister Yevgeny Primakov proposed clearing outstanding wage debts to budget sector workers through increased monetary emissions and alcohol taxes by reviving the state monopoly in the production and wholesale trade of vodka. While monetary expansion will enable the government to pay state workers, it will result in inflation and slash the purchasing power of cash payments without resolving the nonpayments crisis: wage debts will accumulate again in the absence of restructuring and workforce downsizing. Alcohol taxes, estimated to generate revenues to clear half the outstanding state sector debt, may create a continuing source of government revenue for paying budget sector workers; during Soviet days, revenues from the state vodka monopoly yielded as much as 35 percent of state revenues that were reduced to a paltry 2-4 percent after Boris Yeltsin liquidated the state monopoly in May 1992 (New York Times, September 26, 1998. "Russia Moves to Assert More Control Over the Vodka Industry"). 


\begin{tabular}{lccl} 
& \multicolumn{3}{c}{ Panel (A) } \\
Not owed arrears & $\underline{1994}$ & $\underline{1995}$ & $\underline{1996}$ \\
Owed arrears & 7.915 & $14.443^{\mathrm{b}}$ & $12.889^{\mathrm{c}}$ \\
& $11.206^{\mathrm{a}}$ & $26.897^{\mathrm{a}, \mathrm{b}}$ & $25.277^{\mathrm{a}, \mathrm{c}}$
\end{tabular}

$\underline{\text { Panel (B) }}$

Explanatory Variables

dum1995

$0.4716^{\mathrm{a}}$

$0.4074^{\mathrm{a}}$

$(0.0483)$

$(0.0581)$

dum1996

$0.5800^{\mathrm{a}}$

$0.4748^{\mathrm{a}}$

(0.0528)

(0.0683)

Pjowed

$0.6532^{\mathrm{a}}$

$0.4942^{\mathrm{a}}$

$(0.0458)$

Pjowed $\mathrm{x}$ dum1995

-

$0.1948^{\circ}$

(0.1063)

Pjowed $\mathrm{x}$ dum 1996

$0.2621^{a}$

$(0.1070)$

Notes: 1. In Panel (A), each cell entry gives the percentage of respondents (ages 17 to 64) in families with family incomes below regional poverty thresholds (see footnote 6). The first row gives poverty percentages for respondents who reported that they were not owed wages by their employers; the second row gives poverty percentages for people who reported that they were owed wages by their employers. Superscripts $\mathrm{a}, \mathrm{b}$ and $\mathrm{c}$ indicate significant differences (at 10 percent or better) in poverty rates between respondents based on whether or not they were owed wages by their employers between 1994 and 1995 and between 1994 and 1996 respectively.

2. The dependent variable for regressions (1) and (2) in Panel (B) is Pov_index, which is defined as 1 if the family income (adjusted for family structure) fell below the poverty threshold and as 0 if the family income did not fall below the poverty threshold. The regressions are estimated by maximum likelihood probit. The sample size is 7,491 . The coefficient estimates are reported with robust standard errors in parentheses. Significance at the 1, 5 and 10 percent levels are denoted by superscripts a, b, and c, respectively. Each regression additionally includes a constant and control variables for age, tenure, gender, education, region, occupation and industry (the full results are available on request). The variables dum1995 and dum1996 are year dummies for 1995 and 1996, respectively.

* See footnote 8. 
Table 2. The Incidence of Pension Arrears and the Effect of Pension Arrears on the Incidence of Poverty

Panel (A) : Pensions Arrears and Poverty

\begin{tabular}{|c|c|c|c|}
\hline & 1994 & 1995 & 1996 \\
\hline Pension arrears & $44.90^{\mathrm{a}}$ & $71.93^{\circ}$ & $69.47^{\mathrm{a}}$ \\
\hline \multirow[t]{3}{*}{ No pension arrears } & 7.72 & 18.83 & 10.49 \\
\hline & & & \\
\hline & \multicolumn{3}{|c|}{ Panel (B): Incidence of Pension Arrears and Poverty } \\
\hline \multirow[t]{2}{*}{$\begin{array}{l}\text { Explanatory } \\
\text { Variables }\end{array}$} & $\begin{array}{c}\text { Incidence of } \\
\text { Pension Arrears }\end{array}$ & \multicolumn{2}{|c|}{$\begin{array}{c}\text { Effect of Pension Arrears } \\
\text { On the Incidence of Poverty }\end{array}$} \\
\hline & (1) & (2) & (3) \\
\hline Pens30 & - & $\begin{array}{l}1.639^{*} \\
(0.06)\end{array}$ & $\begin{array}{l}1.332^{\circ} \\
(0.19)\end{array}$ \\
\hline Pens30 x dum 1995 & - & - & $\begin{array}{r}0.127 \\
(0.21)\end{array}$ \\
\hline Pens30 x dum 1996 & - & - & $\begin{array}{l}0.424^{\mathrm{b}} \\
(0.20)\end{array}$ \\
\hline dum1995 & $\begin{array}{l}0.566^{2} \\
(0.07)\end{array}$ & $\begin{array}{l}0.541^{2} \\
(0.05)\end{array}$ & $\begin{array}{l}0.542^{4} \\
(0.05)\end{array}$ \\
\hline dum 1996 & $\begin{array}{l}1.585^{\mathrm{a}} \\
(0.07)\end{array}$ & $\begin{array}{c}0.257^{2} \\
(0.06)\end{array}$ & $\begin{array}{l}0.185^{2} \\
(0.06)\end{array}$ \\
\hline
\end{tabular}

Notes: 1. Panel (A) reports the percentage of people who live in families with income below the poverty level. Superscript a denotes a significant difference (at 10 percent or better) in poverty incidence based on whether or not the individual is experiencing pension arrears.

2. In panel (B), maximum likelihood probit estimates are reported with robust standard errors in parentheses. Superscripts $a, b$, and $c$ denote significant at the 1,5 , and 10 percent levels respectively. The dependent variable for regression (1) is Pens 30 , a dummy $=1$ if the respondent had not received pension benefits in the past 30 days. The dependent variable for regressions (2) and (3) is a dummy=1 if the respondent lived in a family with income below the regional poverty threshold. Each regression additionally includes a constant and variables for age, gender, education, and region of residence. We exclude wage, occupation, and industry variables because our focus is on retired pensioners. 


\begin{tabular}{lccc}
\multicolumn{4}{c}{ (A) $\underline{\text { Adpdjb }}$} \\
& $\underline{1994}$ & $\underline{1995}$ & 1996 \\
Owed wages & 4.358 & $6.409^{\mathrm{a}}$ & $5.938^{\mathrm{a}}$ \\
Not owed wages & 4.986 & 4.032 & 4.145
\end{tabular}

(B) Engiea

$\begin{array}{llll}\text { Owed wages } & 8.955^{\mathrm{a}} & 7.363^{\mathrm{a}} & 7.864^{\mathrm{a}} \\ \text { Not owed wages } & 7.435 & 4.912 & 4.814\end{array}$

(C) Multivariate Analysis

\begin{tabular}{|c|c|c|}
\hline Explanatory Variable & Adpdib & Engiea \\
\hline Pjowed & $\begin{array}{r}0.147^{\mathrm{a}} \\
(0.059)\end{array}$ & $\begin{array}{r}0.232^{\mathrm{a}} \\
(0.050)\end{array}$ \\
\hline dum 1995 & $\begin{array}{r}0.029 \\
(0.052)\end{array}$ & $\begin{array}{l}-0.134^{\mathrm{a}} \\
(0.051)\end{array}$ \\
\hline dum 1996 & $\begin{array}{c}0.014 \\
(0.058)\end{array}$ & $\begin{array}{l}-0.135^{b} \\
(0.055)\end{array}$ \\
\hline $\begin{array}{l}\text { (pseudo) } R^{2} \\
\text { Sample size }\end{array}$ & $\begin{array}{c}0.0555 \\
7,857\end{array}$ & $\begin{array}{c}0.0655 \\
7,848\end{array}$ \\
\hline \multicolumn{3}{|c|}{$\begin{array}{l}\text { Notes: } 1 \text {. In panels }(\mathrm{A}) \text { and }(\mathrm{B}) \text {, each cell reports the mean value } \\
\text { (multiplied by } 100 \text { ) for the relevant dummy variable separately for } \\
\text { respondents who were and who were not owed wages. We restrict the } \\
\text { analysis to respondents who reported positive wages. Superscript a } \\
\text { denotes significant differences (at } 10 \text { percent or better), for each year, } \\
\text { between respondents who were and who were not owed wages. } \\
2 \text {. The regressions in panel (C) are estimated by maximum likelihood } \\
\text { probit. The coefficient estimates are reported with robust standard } \\
\text { errors in parentheses. Significance at the } 1 \text { percent and } 5 \text { percent levels } \\
\text { are denoted by superscripts a and b respectively. Each regression } \\
\text { additionally contains the same vector of control variables listed in the } \\
\text { notes to Table } 1 \text { (the full results are available on request). }\end{array}$} \\
\hline
\end{tabular}


Table 4. The Incidence of

Wage Arrears and Intra-Family Transfers

$\begin{array}{lccc} & \text { Panel (A) } & & \\ & & & 1996 \\ \text { Owed Wages } & 1994 & 1995 & \\ \text { Gave money to relatives } & & 15.21^{\mathrm{b}} & 19.94 \\ \text { Amount given to relatives } & 22.29 & 227,925^{\mathrm{b}} & 238,288^{\mathrm{b}} \\ \text { Received money from relatives } & 250,472 & 20.99^{\mathrm{b}} & 22.01^{\mathrm{b}} \\ \text { Amount received by relatives } & 22.07^{\mathrm{b}} & 375,906 & 436,928 \\ & 445,258 & & \\ \text { Not Owed Wages } & & & \\ & & & 17.22 \\ \text { Gave money to relatives } & 22.25 & 303,008 & 379,244^{\mathrm{a}} \\ \text { Amount given to relatives } & 265,646 & 18.22 & 19.34 \\ \text { Received money from relatives } & 19.46 & 377,740 & 504,709 \\ \text { Amount received by relatives } & 422,985 & & \end{array}$

Panel (B)

$\begin{array}{cccc}\begin{array}{c}\text { Gave Money } \\ \text { to Relatives }\end{array} & \begin{array}{c}\text { Amount Given } \\ \text { To Relatives }\end{array} & \begin{array}{c}\text { Received Money } \\ \text { from Relatives }\end{array} & \begin{array}{c}\text { Amount Received } \\ \text { From Relatives }\end{array}\end{array}$

$\begin{array}{lcccc}\text { Pjowed } & -0.067^{\mathrm{c}} & -97870.98^{\mathrm{a}} & 0.143^{\mathrm{a}} & -9243.58 \\ & (0.04) & (33374.64) & (0.04) & (43739.97) \\ \text { dum1995 } & -0.202^{\mathrm{a}} & 21102.71 & -0.036 & -32188.87 \\ & (0.04) & (26774.32) & (0.04) & (39688.85) \\ \text { dum1996 } & -0.133^{\mathrm{a}} & 76621.83^{\mathrm{c}} & 0.020 & 14580.25 \\ & (0.04) & (45264.09) & (0.04) & (60060.71)\end{array}$

Notes: 1. In Panel (A) mean values are reported in each cell. The first and third rows in each set contains the percentages of respondents who gave (or received) transfers to (or from) relatives, the second and fourth rows give the average amounts given (or received) for the group of respondents who gave (or received) funds from relatives. Superscript a in the 1996 column indicates a significant change (at 10 percent or better) between 1994 and 1996; superscript $b$ indicates a significant difference between people who were owed wages and those who were not owed wages.

2. Regressions (1) and (3) are estimated by maximum likelihood probit; regressions (2) and (4) by ordinary least squares. Parameter estimates are reported with standard errors in parentheses. Superscripts $a, b$, and $c$ denote significance levels at 1,5 , and 10 percent respectively. The regressions additionally include a constant, and variables for wage rates, age, gender, education, region of residence, occupation, and industry of employment, and are restricted to people of age 16 through 65 . Regression (2) is run only for people who gave money to relatives. Similarly, regression (4) is run only for people who received money from relatives. 
Table 5a. The Incidence of Wage Arrears and Family

Survival Responses: Home Production, Consumption and Sales

\section{Panel (A)}

\section{Owed Wages}

Consumed own food production

Sold own production

Value of sold own-production

$\underline{\text { Not Owed Wages }}$

Consumed own food production

Sold own production

Value of sold own-production
62.40

7.47

338,978
1995

$69.95^{\mathrm{b}}$

$13.81^{\mathrm{b}}$

427,849

$72.90^{b}$

$12.42^{\mathrm{b}}$

573,612

$10.93^{\mathrm{a}, \mathrm{b}}$

$484,926^{\mathrm{b}}$

Panel (B)

\begin{tabular}{lccc} 
Consumed Own & $\begin{array}{c}\text { Sold Own } \\
\text { Food-Production }\end{array}$ & $\begin{array}{c}\text { Value of Sold } \\
\text { Production }\end{array}$ & $\begin{array}{c}\text { Own-Production } \\
\text { Pjowed }\end{array}$ \\
\cline { 2 - 2 } & $0.227^{\mathrm{a}}$ & $0.317^{\mathrm{a}}$ & 10,669 \\
dum1995 & $(0.04)$ & $(0.05)$ & $(61,837)$ \\
dum1996 & -0.018 & -0.053 & $142,047^{\mathrm{b}}$ \\
& $(0.03)$ & $(0.05)$ & $(72,671)$ \\
& 0.008 & -0.027 & 80,454 \\
& $(0.04)$ & $(0.05)$ & $(66,078)$
\end{tabular}

Notes: 1. Mean (percentage) values are reported in each cell. The first and second rows in each panel contain the percentage of the respondents who consumed (or sold) their ownproduction; the third row in each panel gives the average ruble value of sold own-production (conditional on some positive level of own-production sales). Superscript a in the 1996 column indicates a significant increase (at 10 percent or better) between 1994 and 1996. Superscript $b$ in the top panel indicates a significant difference between people who are owed wages and those who are not owed wages.

2. The first two regressions in Panel (B) are estimated by maximum likelihood probit; the third is estimated by ordinary least squares and is only run for people who sold some portion of their home produced goods. Superscripts $a, b$, and $c$ denote significance levels of 1,5 , and 10 percent respectively. All regressions additionally include a constant, and variables for wage rates, age, gender, education, region of residence, occupation, and industry of employment, and are restricted to people of age 16 through 65 . 
Panel (A)

\begin{tabular}{|c|c|c|c|}
\hline & $\underline{1994}$ & $\underline{1995}$ & 1996 \\
\hline \multicolumn{4}{|l|}{ Owed Wages } \\
\hline Sold family assets & $10.21^{\mathrm{b}}$ & $6.81^{\mathrm{b}}$ & $4.56^{\mathrm{a}, \mathrm{b}}$ \\
\hline Took out a loan & $28.42^{\mathrm{b}}$ & $31.91^{\mathrm{b}}$ & $27.81^{\mathrm{b}}$ \\
\hline Amount borrowed & $593,337^{b}$ & $426,456^{b}$ & $575,732^{b}$ \\
\hline \multicolumn{4}{|l|}{ Not Owed Wages } \\
\hline Sold family assets & 7.55 & 5.28 & $3.05^{\mathrm{a}}$ \\
\hline Took out a loan & 21.05 & 19.07 & $16.95^{\mathrm{a}}$ \\
\hline \multirow[t]{3}{*}{ Amount borrowed } & 86,1046 & 840,886 & $1,094,515^{\mathrm{a}}$ \\
\hline & \multicolumn{2}{|c|}{ Panel (B) } & \\
\hline & $\begin{array}{c}\text { Sold } \\
\text { Family Assets }\end{array}$ & $\begin{array}{l}\text { Took Out } \\
\text { A Loan }\end{array}$ & $\begin{array}{c}\text { Amount } \\
\text { Borrowed }\end{array}$ \\
\hline Pjowed & $0.206^{\mathrm{a}}$ & $0.338^{\mathrm{a}}$ & $-370,970^{a}$ \\
\hline & $(0.05)$ & $(0.04)$ & $(76,085)$ \\
\hline dum1995 & $-0.176^{a}$ & -0.019 & $-126,056^{\mathrm{c}}$ \\
\hline & $(0.05)$ & $(0.04)$ & $(78,057)$ \\
\hline dum 1996 & $\begin{array}{c}-0.551^{a} \\
(0.07)\end{array}$ & $\begin{array}{c}-0.167^{a} \\
(0.04)\end{array}$ & $\begin{array}{r}176,446 \\
(173.016)\end{array}$ \\
\hline
\end{tabular}

Notes: 1. Mean (percentage) values are reported in each cell in Panel (A). The first row in each group contains the percentage of the respondents who sold family assets; the second row reports the percentage who took out a loan; the third row reports the average amount borrowed conditional on having taken out a loan. Superscript a in the 1996 column indicates a significant increase (at 10 percent or better) between 1994 and 1996. Superscript $b$ in the top panel indicates a significant difference between people who are owed wages and those who are not owed wages.

2. The first two regressions in Panel (B) are estimated by maximum likelihood probit; the third is estimated by ordinary least squares and is only run for people who took out a loan. Superscripts $a, b$, and $c$ denote significance levels of 1,5 , and 10 percent respectively. All regressions additionally include a constant, and variables for wage rates, age, gender, education, region of residence, occupation, and industry of employment, and are restricted to people of age 16 through 65 . 


\begin{tabular}{|c|c|c|c|}
\hline \multicolumn{4}{|c|}{ Panel (A) } \\
\hline & $\underline{1994}$ & 1995 & 1996 \\
\hline \multicolumn{4}{|l|}{ Owed Wages } \\
\hline Saved money & $9.98^{\mathrm{b}}$ & 9.08 & $6.48^{\mathrm{a}, \mathrm{b}}$ \\
\hline Amount saved & $614,309^{b}$ & 949,088 & 827,377 \\
\hline Withdrawal from savings & 7.31 & 8.01 & 7.96 \\
\hline Amount withdrawn & $2,254,869$ & $1,634,168$ & $1,363,967$ \\
\hline \multicolumn{4}{|l|}{ Not Owed Wages } \\
\hline Saved money & 13.21 & 10.28 & $9.60^{\star}$ \\
\hline Amount saved & 296,033 & 762,527 & $765,659^{\star}$ \\
\hline Withdrawal from savings & 7.35 & 7.04 & 7.93 \\
\hline \multirow[t]{2}{*}{ Amount withdrawn } & $1,199,606$ & $2,213,603$ & $1,746,341^{\bullet}$ \\
\hline & \multicolumn{3}{|l|}{ Panel (B) } \\
\hline $\begin{array}{l}\text { If Saved } \\
\text { Any Money }\end{array}$ & $\begin{array}{l}\text { Amount } \\
\text { Saved }\end{array}$ & $\begin{array}{l}\text { Took Money } \\
\text { Out of Savings }\end{array}$ & $\begin{array}{l}\text { Amount Taken } \\
\text { from Savings }\end{array}$ \\
\hline Pjowed & $\begin{array}{c}57,517 \\
(113,601)\end{array}$ & $\begin{array}{l}0.074 \\
(0.05)\end{array}$ & $\begin{array}{l}-133,729 \\
(512,089)\end{array}$ \\
\hline dum 1995 & $\begin{array}{c}479,701 \\
(105,847)^{2}\end{array}$ & $\begin{array}{l}-0.017 \\
(0.05)\end{array}$ & $\begin{array}{c}483,311 \\
(676,186)\end{array}$ \\
\hline dum 1996 & $\begin{array}{l}300,900 \\
(77,185)\end{array}$ & $\begin{array}{l}0.018 \\
(0.06)\end{array}$ & $\begin{array}{l}-334,216 \\
(876,707)\end{array}$ \\
\hline \multicolumn{4}{|c|}{$\begin{array}{l}\text { Notes: } 1 \text {. Mean (percentage) values are reported in each cell. The first and second rows in } \\
\text { each panel contain the percentage of the respondents who saved money or withdrew money } \\
\text { from savings; the second and fourth rowa contain the average ruble amounts saved or } \\
\text { withdrawn from savings. Superscript a in the } 1996 \text { column indicates a significant increase (at } \\
10 \text { percent or better) between } 1994 \text { and } 1996 \text {. Superscript b in the top panel indicates a } \\
\text { significant difference between people who are owed wages and those who are not owed } \\
\text { wages. } \\
\text { 2. The first and third regressions in Panel (B) are estimated by maximum likelihood probit; } \\
\text { the second and fourth are estimated by ordinary least squares and are only run for people who } \\
\text { saved money (column 2) or took money out of savings (column 4). Superscripts a, b, and c } \\
\text { denote significance levels of } 1,5 \text {, and } 10 \text { percent respectively. All regressions additionally } \\
\text { include a constant, and variables for wage rates, age, gender, education, region of residence, } \\
\text { occupation. and industry of employment. and are restricted to people of age } 16 \text { through } 65 \text {. }\end{array}$} \\
\hline
\end{tabular}


Table 6. Wage Arrears and the Incidence of Poverty:

The Effect of Intra-Family Transfers and Home Production

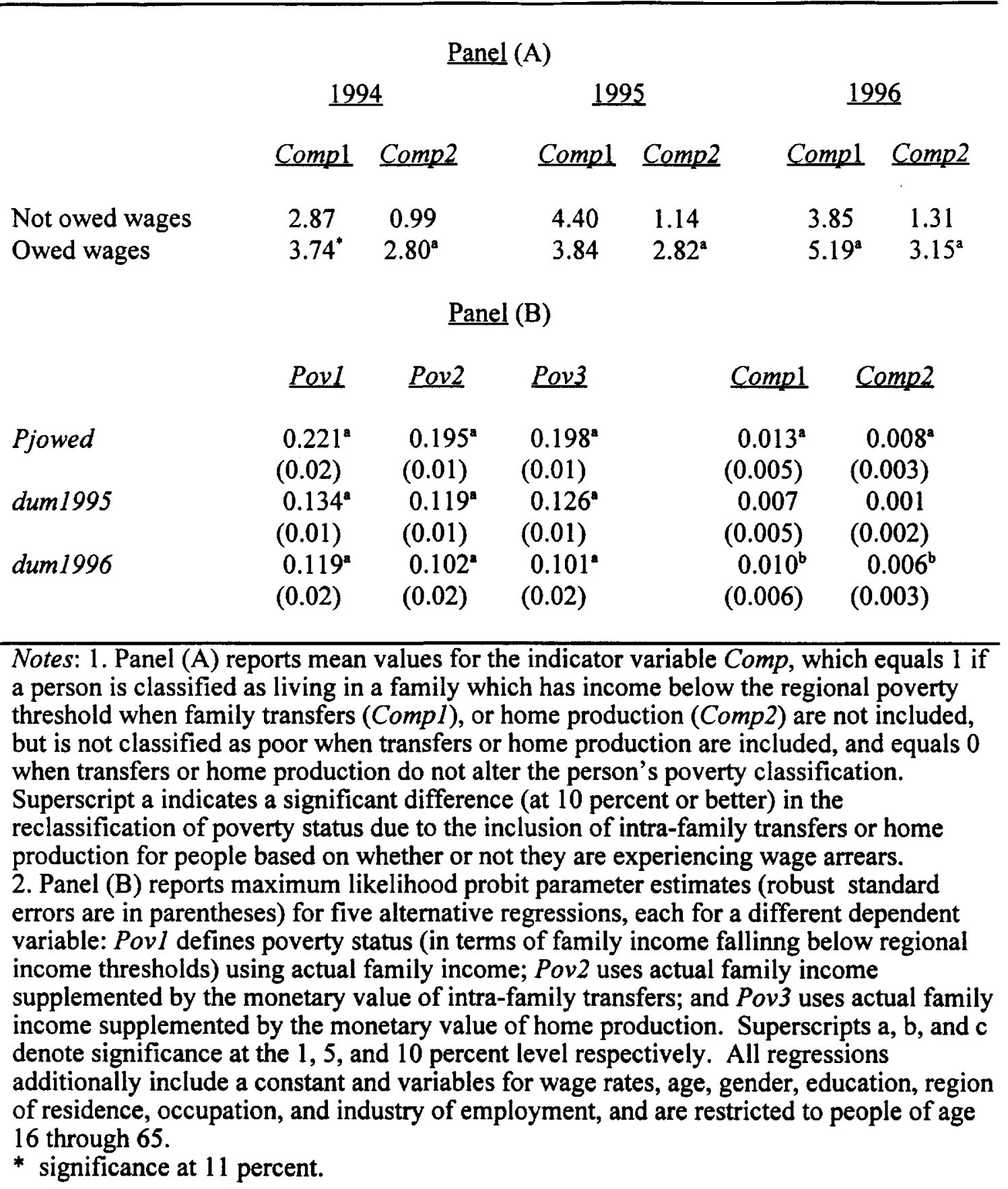




\section{Panel (A)}

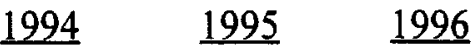

Goodsp: the percentage of respondents

$8.97^{\mathrm{a}}$

$14.68^{\mathrm{b}}$

who are currently owed wages that have

(28.60)

(35.40)

received at least partial payment in goods

Goodsv: the average value of goods

$\begin{array}{lll}222,376 & 162,865^{\mathrm{a}} & 190,069\end{array}$

received by respondents who have

$(279,039) \quad(263,463) \quad(232,048)$

received goods in lieu of wage payments

Panel (B)

Goodsp

(2) $\underline{\ln (\text { Goodsv) }}$

(3)

$-0.351^{\mathrm{b}}$

(0.163)

$-0.122$

$(0.159)$

$(0.085)$

$(0.090)$

0.071

$(0.053)$

$-$

$(0.052)$

$\ln ($ Amtowed $)$

Notes: 1. In Panel (A), annual averages are reported with standard deviations in parentheses. Superscripts $a$ and $b$ denote significant differences (at 10 percent or better) between 1994 and 1995, and between 1995 and 1996 respectively. We restrict the analysis to respondents who were owed wages by their employers (Pjowed $=1$ ). Values reported for the variable Goodsp each year are the percentage of respondents who received goods in lieu of wage payments. The cell entries for the variable Goodsv is the average ruble value of goods received, in lieu of wage payments, for those respondents who did receive goods, i.e. if Goodsp $=1$ and Goodsv>0.

2. Regressions (1) and (2) for Goodsp are estimated by maximum likelihood probit. The $\ln ($ Goodsv) regression is estimated by ordinary least squares. The coefficient estimates are reported with robust standard errors in parentheses. Significance at the 1 percent and 5 percent levels are denoted by superscripts $a$ and $b$ respectively. The sample for regression (2) is restricted to people who indicated that they were owed wages by their employers (Pjowed $=1$ ); the $\ln ($ Goodsv) regression is additionally limited to people who reported receiving goods in lieu of wage payments (Goodsp=1). Each regression additionally contains the vector of control variables listed in the notes to Table 1 (the full results are available on request).

3. Respondents in the military were deleted because none of the people serving in the military reported receiving goods in lieu of wages (Goodsp $=0$ ). 


\section{References}

Aukutsionek, Sergei. “On Types of Barter.” Russian Economic Barometer, vol. 7, 21998.

Cox, Donald, Zereria Eser and Emanuel Jimenez. "Family Safety Nets During Economic Transition: A Study of Inter-Household Transfers in Russia" in Poverty in Russia, edited by Jeni Klugman. Washington D.C.: The World Bank, 1997.

Desai, Padma and Todd Idson. "To Pay or Not to Pay: Managerial Decision Making and Wage Withholding in Russia." Working Paper, Columbia University, October 1998.

Foley, Mark. "Multiple Job Holding in Russia During the Transition," Working Paper, Yale University, August 1997.

Gregory, Paul. "Macroeconomic Policy, Structural Factors, and Poverty: The Russian and Ukranian Transition." Working Paper, 1997.

Hendley, Kathryn, Barry W. Ickes, and Randi Ryterman. "Remonetizing the Russian Economy." Working Paper, 1998.

Klugman, Jeni. "Poverty in Russia: Public Policy and Private Responses." (editor), EDI Development Studies, The World Bank: Washington, D.C., 1997.

Mikhalev, Vladimir. "Poverty Alleviation in the Course of Transition: Policy Options for Russia." Working Paper, European University Institute, 1996.

Milanovic, Branko. "Income, Inequality, and Poverty During the Transition." Working Paper, 1996.

Pendergast, Canice, and Lars Stole. "Non-Monetary Exchange Within Firms and Industry." NBER Working Paper 5765, September 1996.

Popkin, Barry, and Tom Mroz. "Poverty and the Economic Transition in the Russian Federation." Economic Development and Cultural Change, 44: 111-141 (1995).

Russian Economic Trends. Working Centre for Economic Reform, Government of the Russian Federation. Whurr Publishers, Ltd., London, UK (various issues).

Roha, Ronaleen, and Marc Schulhof. "How Barter Saves Cash." Kiplinger's Personal Finance Magazine, vol. 50(2), 1996.

Shisko, Robert, and Bernard Rostker. "The Economics of Multiple Job Holding." American Economic Review, vol. 66, no. 3, June 1976: 298-308.

Stigler, George. “Reciprocity.” Antitrust Law \& Economics Review, Spring 1969. 
Woodruff, David. "Barter of the Bankrupt: The Politics of Demonetization in Russia's Federal State." in Ethnographies of Transition, Burawoy and Verdery, eds., 1996.

Yakovlev, Andrey. "Barter and Clearing Schemes: How to Define Basic Concepts." Russian Economic Barometer, vol. 7, 21998. 


\title{
1998-1999 Discussion Paper Series
}

\author{
Department of Economics \\ Columbia University \\ 1022 International Affairs Bldg. \\ 420 West 118th Street \\ New York, N.Y., 10027
}

The following papers are published in the 1998-99 Columbia University Discussion Paper series which runs from early November to October 31 of the following year (Academic Year).

The following is the Columbia University, Economics Department's website where viewers may access more information about the Discussion Paper series.

\section{Http:/www.columbia.edu/cu/economics/}

All 1997-98, 1998-99 and future papers will be acessible on-line at the following website:

\section{Http://www.ssrn.com}

Discussions papers that are not available on-line maybe obtained by written request to the Economics Department. Please check the Ordering Papers section for details.

\section{Copy Requests}

To order 1996-97 and prior discussion papers, please write to the Discussion Paper Coordinator at the address below, along with a check for the appropriate amount, made payable to:

Department of Economics, Columbia University. Please be sure to indicate the discussion paper number or the particular series in your written request. Orders cannot be processed without payment, and they cannot be taken over the phone, or by fax or email.

Past discussion papers (1996-97 and prior papers) are available for purchase in U.S. dollars only, at the cost of:

US: per paper $\$ 4.00 /$ per series: $\$ 140.00$

Canada: per paper $\$ 5.00 /$ per series: $\$ 150.00$

Overseas: per paper $\$ 7.00 /$ per series $\$ 185.00$ 
1998-99 Discussion Papers

Economics Department, Columbia University

\begin{tabular}{|c|c|c|}
\hline Seriestino & 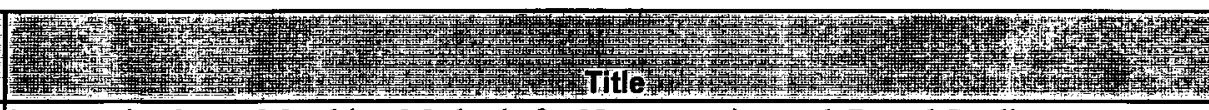 & 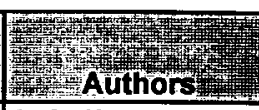 \\
\hline $9899-01$ & Propensity Score Matching Methods for Non-experimental Causal Studies & Dehejia, $\mathrm{R}$. \\
\hline $9899-02$ & Institutional Solutions to the Principal-Agent Problem in African Health Care & $\begin{array}{l}\text { Leonard, } \mathrm{K} . \\
\text { Leonard, D. }\end{array}$ \\
\hline 9899-03 & The Economics of Repeated Extortion & $\begin{array}{l}\text { Choi, J.P. } \\
\text { Thum, M. }\end{array}$ \\
\hline 9899-04 & To Pay or Not to Pay: Managerial Decision making and Wage Withholding in Russia & $\begin{array}{l}\text { Desai, P. } \\
\text { Idson, T. }\end{array}$ \\
\hline $9899-05$ & Wage Arrears, Poverty, and Family Survival Strategies in Russia & $\begin{array}{l}\text { Desai, P. } \\
\text { Idson, T. }\end{array}$ \\
\hline
\end{tabular}

